\title{
Niche separation in common prostome freshwater ciliates: the effect of food and temperature
}

\author{
Thomas Weisse $^{1, *}$, Nicole Karstens ${ }^{2}$, Volker C. L. Meyer ${ }^{2, * *}$, Lore Janke ${ }^{2}$, \\ Sabine Lettner ${ }^{1}$, Kathrin Teichgräber ${ }^{2}$ \\ ${ }^{1}$ Institute for Limnology of the Austrian Academy of Sciences, Mondseestrasse 9, 5310 Mondsee, Austria \\ ${ }^{2}$ Max Planck Institute for Limnology, PO Box 165, 24306 Plön, Germany
}

\begin{abstract}
We characterized the ecological niches of several planktonic prostome ciliates with respect to their food demand and temperature. We found intergeneric differences between Balanion planctonicum and the 2 Urotricha spp., U. furcata and U. farcta. There were also significant interspecific differences within the genus Urotricha and intraspecific differences between 2 Balanion spp. and 3 U. furcata isolates from distant lakes. Relative to Urotricha spp., Balanion appeared to be the superior competitor at low to medium food concentrations and reached high growth rates at moderate temperatures. The threshold prey concentration for positive population growth of $B$. planctonicum was lower than that obtained for the 2 Urotricha spp., but higher than that reported earlier for the marine species, B. comatum. A third Urotricha species, U. castalia, was investigated for its temperature response only. The temperature response revealed species-specific temperature adaptation between $B$. planctonicum and the sympatric $U$. furcata, and further differences within the genus Urotricha: U. farcta grew fastest at high temperatures; U. castalia was adapted to low temperatures; and $U$. furcata peaked at moderately warm temperatures.
\end{abstract}

KEY WORDS: Ciliates · Balanion spp. $\cdot$ Urotricha spp. $\cdot$ Growth $\cdot$ Ingestion rate $\cdot$ Clonal differences Resale or republication not permitted without written consent of the publisher

\section{INTRODUCTION}

Small prostome ciliates $(<30 \mu \mathrm{m})$ in the genera Urotricha and Balanion play a major role in the microbial food web of many freshwater lakes and reservoirs (Müller 1989, Sommaruga \& Psenner 1993, Salbrechter \& Arndt 1994, Schönberger 1994, Šimek et al. 1995, Macek et al. 1996). The ecological importance of these planktonic ciliates was first discovered in prealpine, mesoeutrophic Lake Constance (Bodensee), Germany (Müller 1989, Foissner et al. 1990, Müller et al. 1991). In this lake, the peak abundance of $B$. planctonicum may exceed 60 cells ml ${ }^{-1}$ and that of the sympatric spe-

\footnotetext{
*E-mail: thomas.weisse@oeaw.ac.at

${ }^{* *}$ Present address: Leibnitz-Institute of Freshwater Ecology and Inland Fisheries, Department of Shallow Lakes and Lowland Rivers, Müggelseedamm 301, 12587 Berlin, Germany
}

cies U. furcata 40 cells $\mathrm{ml}^{-1}$ (Müller et al. 1991); together, these 2 species account for $75 \%$ of total ciliate cell numbers during spring (Müller 1989) and contribute $40 \%$ of total ciliate abundance to the annual average (Müller et al. 1991, Weisse \& Müller 1998). The numerical dominance of small Prostomatida was interpreted as a unique feature of Lake Constance (Müller 1989). Since then, however, B. planctonicum, $U$. furcata and other small Urotricha species have been recorded in high numbers in many lakes, reservoirs and ponds from Europe and North America (summarized by Foissner et al. 1999). Except for the oligotrichs, urotrichs are the most typical and common freshwater plankton ciliates (Foissner et al. 1999).

Although both genera occur in the pelagic zone throughout the year, these prostomes usually peak in relation to phytoplankton maxima when they reach cell numbers of several tens $\mathrm{ml}^{-1}$ (Müller 1989, Müller et al. 1991, Sommaruga \& Psenner 1993, Schönberger 
1994). If food is abundant, cell numbers of small Prostomatida can be even higher; for instance, 288 cells $\mathrm{ml}^{-1}$ of Urutricha furcata and $U$. farcta have been recorded from a hypertrophic Danish lake (Jürgens et al. 1999).

Both Balanion sp. and Urotricha sp. prey intensely on small cryptophytes (Müller 1991, Müller et al. 1991, Weisse \& Müller 1998) and thus compete both with each other and with rotifers and crustacea for the same algal food (Weisse \& Frahm 2001a). These ciliates may be the most important herbivores during spring (Weisse et al. 1990, Müller et al. 1991), contribute substantially to the total secondary production (Straile 1998 and references therein), and are significant food for rotifers and planktonic crustacea (Rothhaupt \& Güde 1996, Jürgens et al. 1999, Weisse \& Frahm $2001 b)$. Insight into the niche partitioning of the small prostome ciliate species would, therefore, lead to an improved understanding of the functioning of the planktonic food web.

The effect of temperature (Müller \& Geller 1993, Weisse \& Montagnes 1998, Montagnes \& Weisse 2000) and the feeding ecology of Balanion planctonicum (Müller \& Schlegel 1999) and the similar-sized marine species B. comatum (Jakobsen \& Hansen 1997) have already been investigated. In this study we extend these previous investigations on the ecology of $B$. planctonicum and 3 Urotricha spp., characterizing their respective ecological niches. Our hypothesis was that the niches of the sympatric ciliate species differ with respect to key environmental parameters. We considered food supply, temperature, and the interactions with competitors and predators as major parameters affecting the niche widths of planktonic ciliates. The mutual interactions of Urotricha spp. and B. planc- tonicum with sympatric rotifers of the genus Keratella have been presented elsewhere (Weisse \& Frahm 2001a,b).

In this study we focused on the intergeneric comparison between Balanion planctonicum and Urotricha furcata, which coexist in many freshwater environments. To account for interspecific differences among members of the same genus, we also included $U$. farcta and $U$. castalia, 2 other common freshwater ciliate species (Foissner et al. 1999). We also compared different isolates of B. planctonicum and of $U$. furcata to test for intraspecific, most likely clonal, differences (Weisse \& Montagnes 1998).

\section{MATERIAL AND METHODS}

Study organisms. Balanion planctonicum (Foissner, Oleksiv \& Müller 1990) Foissner, Berger \& Kohmann 1994 is the only member in this genus that is common in freshwater lakes (Foissner et al. 1999). The species was originally described by Foissner et al. (1990) as Pseudobalanion planctonicum and placed into a new genus but, due to the presence of an ultrastructural detail, the dorsal brosse (Bardele 1999), has since then been synonymized with Balanion Wulff, 1919 (Foissner et al. 1999). Live cell size is $\sim 20 \times 15 \mu \mathrm{m}$ (Foissner et al. 1990); the average live cell volume is $\sim 1800 \mu^{3}$ (Müller \& Geller 1993). However, the volume of Balanion and of the other species investigated varies widely with the nutritional status (Müller 1991, Jakobsen \& Hansen 1997) and the isolate investigated (Table 1). B. planctonicum was first isolated from surface waters of Lake Constance (Bodensee), Germany in April 1989

Table 1. Maximum growth rates $\left(\mu_{\max }\right)$ and doubling times $(G)$ at $15 \pm 1^{\circ} \mathrm{C}$, corresponding ingestion rates $(I)$, cell volumes of live and Lugol's fixed cells and gross growth efficiencies (GGE) of the ciliate species and strains studied. L.C.: Lake Constance; L.M.: Lake Mondsee; L.Sch.: Lake Schöhsee; nd: not determined

\begin{tabular}{|c|c|c|c|c|c|c|c|c|c|}
\hline \multirow[t]{2}{*}{ Species } & \multirow{2}{*}{$\begin{array}{l}\text { Origin/year } \\
\text { of isolation }\end{array}$} & \multirow{2}{*}{$\begin{array}{l}\mu_{\max } \\
\left(\mathrm{d}^{-1}\right)\end{array}$} & \multirow{2}{*}{$\begin{array}{c}G \\
(\mathrm{~h})\end{array}$} & \multirow{2}{*}{$\begin{array}{c}I(\text { Crypt } \\
\left.\text { ciliate }^{-1} \mathrm{~h}^{-1}\right)\end{array}$} & \multicolumn{2}{|c|}{ Biovolume $\left(\mu \mathrm{m}^{3}\right)$} & \multicolumn{2}{|c|}{ GGE (\%) } & \multirow[t]{2}{*}{ Source } \\
\hline & & & & & Live & Fixed & Live & Fixed & \\
\hline Balanion planctonicum & L.C./1989 & 1.01 & 16.5 & 0.2 to 4.4 & $\sim 1800$ & 1240 & & 5 to 24 & $\begin{array}{c}\text { Müller (1991), } \\
\text { Müller \& Geller (1993) }\end{array}$ \\
\hline Balanion planctonicum & L.C./1993 & 1.87 & 8.9 & 6.6 & nd & nd & $9.7^{\mathrm{a}}$ & $7.2^{\mathrm{b}}$ & Müller \& Schlegel (1999) \\
\hline Balanion planctonicum & L.C./1993 & 1.03 & 16.1 & 2.0 & nd & 1700 & $17.7^{\mathrm{a}}$ & 13.0 & This study \\
\hline Balanion planctonicum & L.M./1999 & 1.42 & 11.7 & 2.2 & nd & 2330 & $31.1^{\mathrm{a}}$ & 22.9 & This study \\
\hline Balanion comatum & Øresund/1995 & 1.39 & 12.0 & 1.9 & nd & $\sim 2500$ & & 32 & Jakobsen \& Hansen (1997) \\
\hline Urotricha furcata & L.C./1988 & 0.75 & 22.2 & nd & $\sim 3900$ & 2750 & nd & nd & Müller \& Geller (1993) \\
\hline Urotricha furcata & L.C./1988 & 0.86 & 19.5 & 3.8 & nd & 3150 & $15.1^{\mathrm{a}}$ & 10.6 & This study \\
\hline Urotricha farcta & L.Sch./1996 & 1.68 & 9.9 & 2.1 & nd & $\sim 3350$ & & 39.9 & This study \\
\hline Urotricha castalia & L.C./1988 & 0.65 & 25.7 & nd & nd & $\sim 9750$ & & nd & This study \\
\hline
\end{tabular}


(Müller 1991). Results presented in this study were obtained either with a Balanion strain that was isolated by H. Müller (Limnological Institute Constance) from the same lake in 1993 or with a Balanion strain isolated by H. Müller from Lake Mondsee, Austria in autumn 1999.

Urotricha furcata Schewiakoff 1893 has an average live volume of $\sim 3900 \mu^{3}$ (Müller \& Geller 1993), slightly larger than Balanion planctonicum, although the species largely overlap in size (Foissner et al. 1990). In this study we used isolates of this species obtained from surface waters of Lake Constance, southern Germany, Lake Schöhsee, northern Germany, and Lake Mondsee, Austria. These lakes are of comparable mesotrophic status and temperature patterns (summarized in Montagnes \& Weisse 2000) but are 300 to $900 \mathrm{~km}$ apart.

Urotricha farcta Claparède \& Lachmann 1859 is usually slightly larger than U. furcata (Weisse \& Montagnes 1998, Foissner et al. 1999, Montagnes \& Weisse 2000). U. farcta was isolated by one of us (T.W.) from the littoral zone of Lake Schöhsee in spring 1996.

Urotricha castalia Muñoz, Télez \& FernandezGaliano 1987 has a live cell size of 30 to $40 \mu \mathrm{m} \times 20$ to $30 \mu \mathrm{m}$ (Foissner \& Pfister 1997, Foissner et al. 1999) and an average biovolume of $9750 \mu^{3}$ of Lugol's fixed cells at $15^{\circ} \mathrm{C}$ (this study), making it the largest of the 4 prostome ciliate species investigated. The species was first described by Muñoz et al. (1987) from an artificial Spanish pond and redescribed by Foissner \& Pfister (1997) with material provided by H. Müller from Lake Constance. This isolate was also used in the present study.

Note that all ciliate strains used in this study have been kept as non-clonal, non-axenic batch cultures, i.e., each culture was composed of a single species but, probably, not of a single clone. It is, however, possible that single clones best adapted to the laboratory conditions had outcompeted all other clones that were originally present in the course of the rearing of the cultures.

Food organism. All ciliate isolates were maintained on the small cryptophyte Cryptomonas sp. (SAG strain \#26.80, provided by the Culture Collection of Algae in Göttingen, Germany) as food. The average cell volume of Cryptomonas sp. is $\sim 280 \mu^{3}$ (Weisse \& Kirchhoff 1997) but may also vary under standard laboratory conditions (Lettner 2001, this study). We converted cell volume $\left(V\right.$, in $\left.\mu \mathrm{m}^{3}\right)$ to carbon $\left(\mathrm{C}\right.$, in $\mathrm{pg}$ cell $\left.^{-1}\right)$ using the equation $\mathrm{C}=0.109 V^{0.991}$ (Montagnes et al. 1994). We thus assumed an average cellular carbon content of 29 pg C for Cryptomonas sp.

Ciliate stock cultures were maintained on a $12 \mathrm{~h}$ light:12 h dark cycle at an irradiance of 30 to $40 \mu \mathrm{mol}$ photons $\mathrm{m}^{-2} \mathrm{~s}^{-1}$ and at a temperature of $15 \pm 2{ }^{\circ} \mathrm{C}$.
Experimental design. All stock cultures and experiments were conducted in modified Woods Hole medium (MWC, Guillard \& Lorenzen 1972) without dilution (Urotricha spp. and most experiments with Balanion planctonicum from Lake Constance) or with an approximately $1: 1$ dilution by sterile filtered $(<0.2 \mu \mathrm{m})$ lake water (B. planctonicum from Lake Mondsee and some batch culture experiments with $B$. planctonicum from Lake Constance). Experiments were run in $250 \mathrm{ml}$ culture flasks or in sterilized 6 well (10 ml volume) tissue plates in dim light (10 to $30 \mu \mathrm{mol}$ photons $\mathrm{m}^{-2} \mathrm{~s}^{-1}$ ) under a 12:12 h light:dark cycle. The experimental volume in each well was $8 \mathrm{ml}$. The experimental temperature was $15 \pm 1^{\circ} \mathrm{C}$, if not stated otherwise. For the temperature response experiments, ciliates were gradually acclimated to the experimental temperatures over a period of 2 to $5 \mathrm{~d}$. In ciliate grazing experiments, containers with the same algal concentrations but without ciliates served as controls. The ciliates were taken from their respective stock cultures in exponential growth phase and adapted to the experimental food and temperature conditions for at least $48 \mathrm{~h}$ before the beginning of the experiments.

The growth and grazing experiments lasted 2 to $7 \mathrm{~d}$. Subsamples ( 2 to $5 \mathrm{ml}$ ) for ciliates were taken daily and fixed with Lugol's iodine. Algal abundance in each container was repeatedly measured by means of an electronic particle counter $\left(\mathrm{CASY}^{\circledR}\right.$ 1-Model TTC, Schärfe System, Weisse \& Kirchhoff 1997) during both the acclimation and the experimental period. Two methods were used to establish numerical and functional responses for the ciliates. In most experiments (Balanion planctonicum from Lake Constance in undiluted MWC medium, Urotricha furcata and U. farcta), algae were adjusted daily to the experimental concentration by adding algae from stock cultures or diluting with MWC medium. This semi-continuous culture technique (Montagnes 1996) provided a relatively constant food supply during the experiments. Additionally, growth and grazing rates were calculated from changes in cell numbers of the ciliates and their prey from simple batch cultures (e. g., Müller 1991, Müller \& Geller 1993). This method was applied in the experiments with $B$. planctonicum with a 1:1 dilution by sterile filtered lake water and in the experiments with $U$. castalia. Initial algal concentrations in the growth and grazing experiments ranged from 1 to $2 \times 10^{5}$ cells ml $^{-1}$.

Cell numbers of Lugol's fixed ciliates in growth and grazing experiments were measured microscopically using a Sedgewick Rafter cell or settling chambers of 1 or $2 \mathrm{ml}$ volume. Algal concentrations were also measured in these samples to check for the precision of the electronic cell count measurements.

All experiments were conducted in triplicate. Results reported are mean $\pm 1 \mathrm{SD}$. 
Calculation of experimental results. Ciliate growth rate $(\mu)$ is defined as the change in population size assuming exponential growth according to the equation:

$$
\mu=\frac{\left(\ln N_{\mathrm{t}}-\ln N_{0}\right)}{\left(t_{1}-t_{0}\right)}
$$

where $N_{\mathrm{t}}$ and $N_{0}$ are final and initial population sizes, and $t_{0}$ and $t_{1}$ are initial and final time in days.

Ciliate ingestion rate $\left(I\right.$, in Cryptomonas ciliate $\left.{ }^{-1} \mathrm{~h}^{-1}\right)$ was calculated according to (Frost 1972) and (Heinbokel 1978):

$$
I=\frac{\left(C_{\mathrm{m}} \times g\right)}{R_{\mathrm{m}}}
$$

where $g$ is the grazing rate $\left(\mathrm{h}^{-1}\right), R_{\mathrm{m}}$ is the ciliate abundance and $C_{\mathrm{m}}$ is the mean Cryptomonas sp. abundance $\left(\mathrm{ml}^{-1}\right)$ in the experimental containers. The latter was calculated as follows:

$$
C_{\mathrm{m}}=\frac{C_{0} \times\left(\mathrm{e}^{(k-g) \times \Delta t}-1\right)}{\Delta t \times(k-g)}
$$

where $C_{0}$ is the initial Cryptomonas abundance and $k$ denotes Cryptomonas population growth rate in the controls without ciliates. The grazing rate $(g)$ was calculated as follows:

$$
g=\frac{\ln \left(C C_{\mathrm{t}} / C C_{0}\right)-\ln \left(C_{\mathrm{t}} / C_{0}\right)}{\Delta t}
$$

where $C C_{0}$ and $C C_{\mathrm{t}}$ are the initial and final Cryptomonas numbers in the controls and $C_{0}$ and $C_{\mathrm{t}}$ are the inital and final Cryptomonas concentrations in the containers with ciliates.

Numerical and functional response data were fitted to a modified Michaelis-Menten model (Holling's Type II functional response; Holling 1959). The Michaelis-Menten equation was modified by including a positive $x$-axis intercept, using the MarquardtLevenberg algorithm of the graphing software SigmaPlot (Version 6.10, SPSS Inc., Chicago, IL). For the numerical response data, the equation is as follows:

$$
\mu=\frac{\mu_{\max }\left([C]-x^{\prime}\right)}{k_{\mathrm{t}}+\left([C]-x^{\prime}\right)}
$$

where $\mu$ is growth rate, $\mu_{\max }$ is the maximum growth rate, $[C]$ is Cryptomonas sp. abundance, $x^{\prime}$ is the $x$-axis intercept or threshold Cryptomonas concentration where $\mu=0$ and $\mathrm{k}_{\mathrm{t}}$ is a constant. The units are the same as in Eqs (1) \& (2). For the functional response data, $\mu$ and $\mu_{\max }$ were replaced by the respective terms $I$ and $I_{\max }$.

Gross growth efficiency (GGE) or 'yield' of the ciliates was calculated according to Eq. (6) (Fenchel 1982, Jakobsen \& Hansen 1997):

$$
\mathrm{GGE}=\frac{\mu \times V o l_{\mathrm{cil}}}{\left(I \times V o l_{\mathrm{cry}}\right)}
$$

where $\mathrm{Vol}_{\text {cil }}$ and $\mathrm{Vol}_{\text {cry }}$ are the average cell volumes of ciliates and algae, respectively, and $I$ is the ingestion rate (algal cells $\mathrm{cil}^{-1} \mathrm{~h}^{-1}$ ). The generation time $G$ of the ciliates is:

$$
G=\ln 2 / \mu
$$

Statistical analyses. We used Student's $t$-test, 1-way ANOVA, 2-way ANOVA, Tukey's test and analysis of covariance procedures to test for significant differences in the growth rates between the species and isolates. All statistical analyses were performed using SigmaStat (Version 2.03, SPSS Inc.).

\section{RESULTS}

\section{Response to food supply}

The prostome species we investigated can be easily maintained in batch cultures with small cryptophytes as food. We observed repeatedly characteristic differences between Balanion planctonicum and Urotricha furcata in response to the changing food supply (Fig. 1). B. planctonicum exploited its food sources until virtually no algae were left and, thereafter, died off (Fig. 1a). U. furcata, in contrast, stopped growing once the cryptophytes had declined to a lower critical concentration in the range of 1.3 to $1.5 \times 10^{4}$ Cryptomonas $\mathrm{ml}^{-1}$. Cell numbers of $U$. furcata then decreased, while the algal concentration remained stable (Fig. 1b). Different from B. planctonicum, U. furcata did not become extinct in illuminated batch cultures with suitable algal food. At $15^{\circ} \mathrm{C}$, a relatively stable state between algal and ciliate cell numbers was reached several weeks after inoculating the cultures (data not shown). In fact, we have maintained $U$. furcata cultures with Cryptomonas sp. without exchanging the medium for several months.

Similar predator-prey cycles also emerged in batch cultures with the second Urotricha species, U. farcta (Fig. 2). We observed some minor differences in these cycles of $U$. farcta and Cryptomonas sp. grown at 15 and $20^{\circ} \mathrm{C}$. The periods were slightly shorter at the higher temperature, and the predator-prey cycles became blurred in the $20^{\circ} \mathrm{C}$ treatment toward the end of the experiment because the parallel batch cultures started to run out of phase (Fig. 2b). Accordingly, the $\mathrm{SD}$ of the means increased toward the end of this experiment. The minimum algal concentration was $\sim 2 \times 10^{3}$ Cryptomonas $\mathrm{ml}^{-1}$ at both temperatures.

The different feeding strategies of Balanion planctonicum and both Urotricha spp. were apparent in 

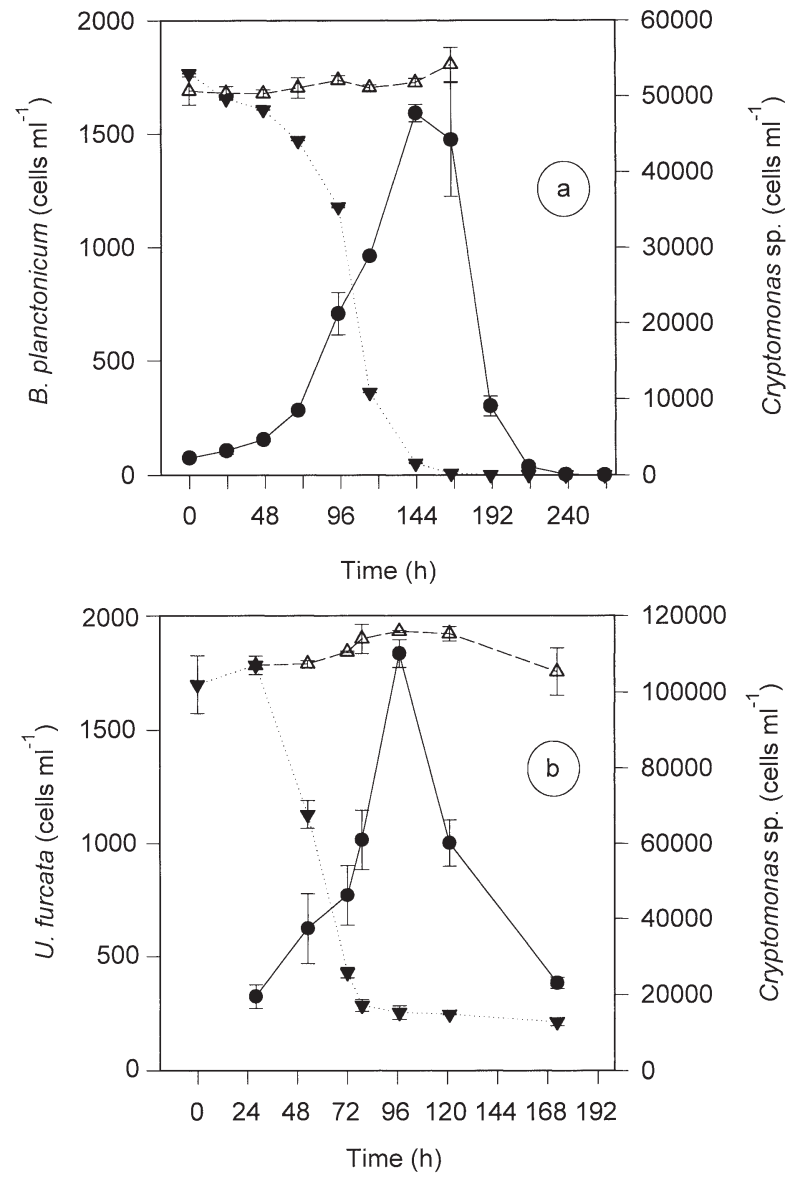

Fig. 1. Batch culture experiments with (a) Balanion planctonicum and (b) Urotricha furcata (๑) at $15^{\circ} \mathrm{C}$. Cryptomonas sp. strain $26.80(\boldsymbol{\nabla})$ served as food in both experiments. $(\Delta)$ Algal concentrations in controls without ciliates. Symbols indicate mean values; error bars $=1 \mathrm{SD}$

their numerical and functional responses. The growth rate of all 3 species in relation to food concentration (numerical response) followed the modified MichaelisMenten model (Eq. 5). Low algal concentrations supported positive growth rates of $B$. planctonicum (Fig. 3a). There was no difference between growth rates estimated from the semi-continuous cultures without addition of sterile filtered lake water and batch cultures with the addition of sterile filtered lake water. Growth rates measured for the $B$. planctonicum isolate from Lake Mondsee at high algal concentrations $(>1 \times$ $10^{5}$ Cryptomonas $\mathrm{ml}^{-1}$ ) fitted in the curve calculated for the $B$. planctonicum isolate from Lake Constance. The model yielded a threshold concentration of $1430 \pm$ 290 Cryptomonas cells $\mathrm{ml}^{-1}$ (equivalent to $\sim 40 \mathrm{ng} \mathrm{C}$ $\mathrm{ml}^{-1}$ ), a constant $\mathrm{k}_{\mathrm{t}}$ of $4700 \pm 1060$ Cryptomonas $\mathrm{ml}^{-1}$ and a maximum ciliate growth rate of $1.03 \pm 0.05 \mathrm{~d}^{-1}$. All model parameters were significant $(\mathrm{p}<0.0001)$.

Compared with Balanion planctonicum, the critical threshold food concentration below which ciliate mor- tality occurred and population size decreased was much higher in Urotricha furcata (Fig. 3b). The latter needed a minimum cryptophyte concentration of $13200 \pm 700$ cells ml$^{-1}$ (equivalent to $\sim 380 \mathrm{ng} \mathrm{C} \mathrm{ml}^{-1}$ ) to increase their population size. The constant $\mathrm{k}_{\mathrm{t}}$ was $\sim 18400$ Cryptomonas cells $\mathrm{ml}^{-1}$. The model yielded a maximal growth rate of $0.86 \pm 0.07 \mathrm{~d}^{-1}$ for $U$. furcata at the experimental temperature of $15^{\circ} \mathrm{C}$. The other Urotricha species, U. farcta, had a threshold concentration of $5630 \pm 870$ Cryptomonas cells $\mathrm{ml}^{-1}(\sim 160 \mathrm{ng} \mathrm{C}$ $\mathrm{ml}^{-1}$ ), a constant $\mathrm{k}_{\mathrm{t}}$ of $\sim 25900$ cells ml ${ }^{-1}$ and a maximum growth rate of $1.68 \pm 0.21 \mathrm{~d}^{-1}$ (Fig. $4 \mathrm{a}$ ).

The functional response was also different for the 3 ciliate species. Ingestion rates of Urotricha farcta increased with algal concentrations up to $\sim 1.2 \times$ $10^{5}$ cells ml $^{-1}$ (Fig. 4b). The modified Michaelis-Menten model yielded a maximum ingestion rate of $4.0 \pm$ 0.8 Cryptomonas ciliate ${ }^{-1} \mathrm{~h}^{-1}$ and a very high constant $\mathrm{k}_{\mathrm{t}}$ of $\sim 1.4 \times 10^{5}$ prey cells $\mathrm{ml}^{-1}$. These predicted parameters may be overestimates, if an asymptote is not adequately predicted by the model. The threshold value was insignificant $(p=0.17)$. Concerning the paucity of the data at high food concentrations, a firm conclusion about the shape of the functional response curve in $U$. farcta cannot be made.

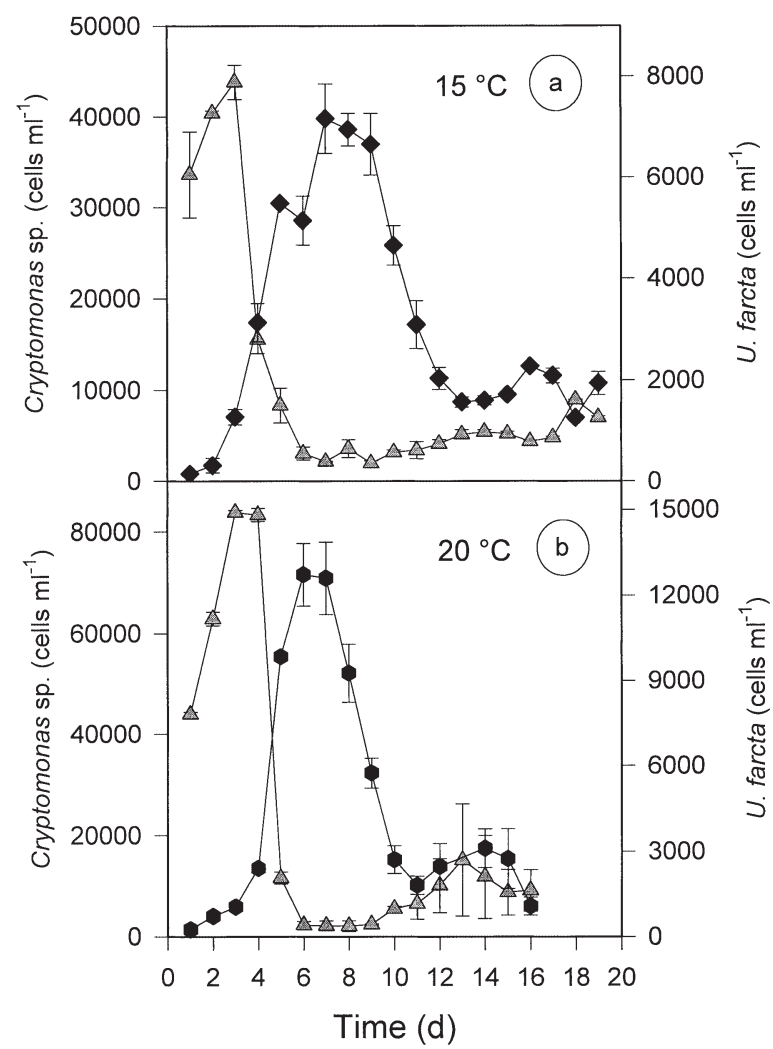

Fig. 2. Batch culture experiments with Urotricha farcta ( $\bullet$ and - ) and Cryptomonas sp. ( $\Delta$ ) as food at (a) $15^{\circ} \mathrm{C}$ and (b) $20^{\circ} \mathrm{C}$. Symbols indicate mean values; error bars $=1 \mathrm{SD}$ 


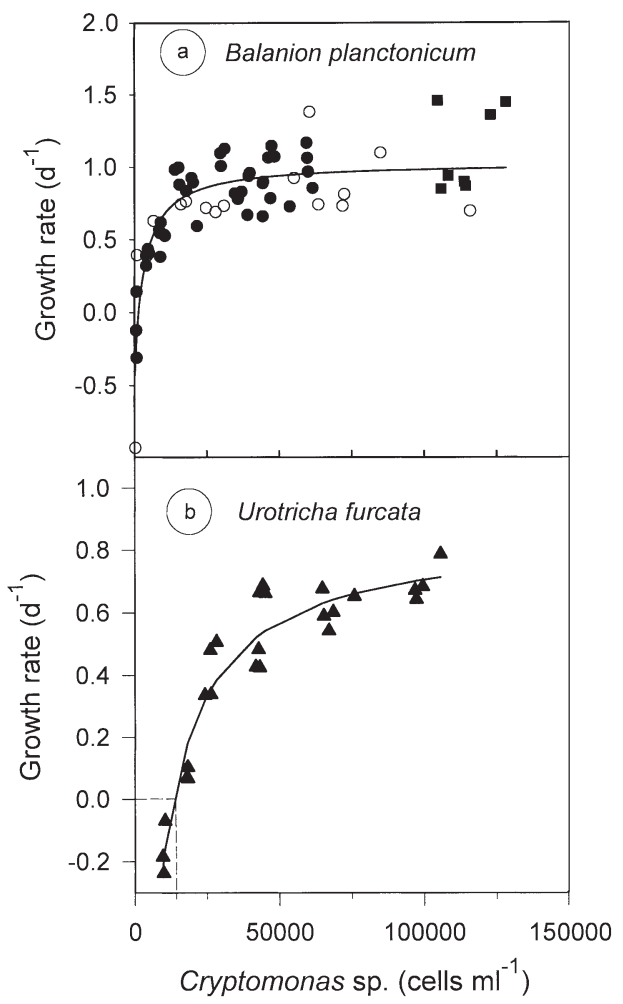

Fig. 3. Growth rates of (a) Balanion planctonicum and (b) Urotricha furcata versus food concentration (numerical response) at $15^{\circ} \mathrm{C}$. Experiments with the B. planctonicum strain from Lake Constance were conducted as semi-continuous cultures in pure MWC medium (•) or as batch cultures in WC medium diluted with sterile filtered lake water (O). (ロ) Batch culture experiments with $B$. planctonicum from Lake Mondsee performed in diluted WC medium. Solid lines represent the modified Michaelis-Menten fit to the data (Eq. 5). Dashed lines in (b) indicate the threshold food concentration where growth rate $(\mu)=0$

The ingestion rate of Balanion planctonicum increased over a wide range of food concentrations, and there was no significant threshold prey concentration below which $B$. planctonicum stopped feeding (Fig. 5a). The scattering of the data was, however, much larger than in the experiments with the 2 Urotricha sp., and Eq. (5) did not provide significant parameter estimates. Food uptake of $U$. furcata was relatively constant ( 3 to 4 Cryptomonas ciliate ${ }^{-1} \mathrm{~h}^{-1}$ ) at food concentrations ranging from 5 to $9 \times 10^{4}$ prey cells $\mathrm{ml}^{-1}$ (Fig. 5b); the modified Michaelis-Menten model indicated a feeding threshold of $13350 \pm 740$ Cryp-

Fig. 5. Ingestion rates of (a) Balanion planctonicum and (b) Urotricha furcata versus food (Cryptomonas sp. [Crypt.]) concentration (functional response) at $15^{\circ} \mathrm{C}$. Symbols and line in the upper panel correspond to those used in Fig. 3a. Solid lines represent the curve fitted according to Eq. (5)

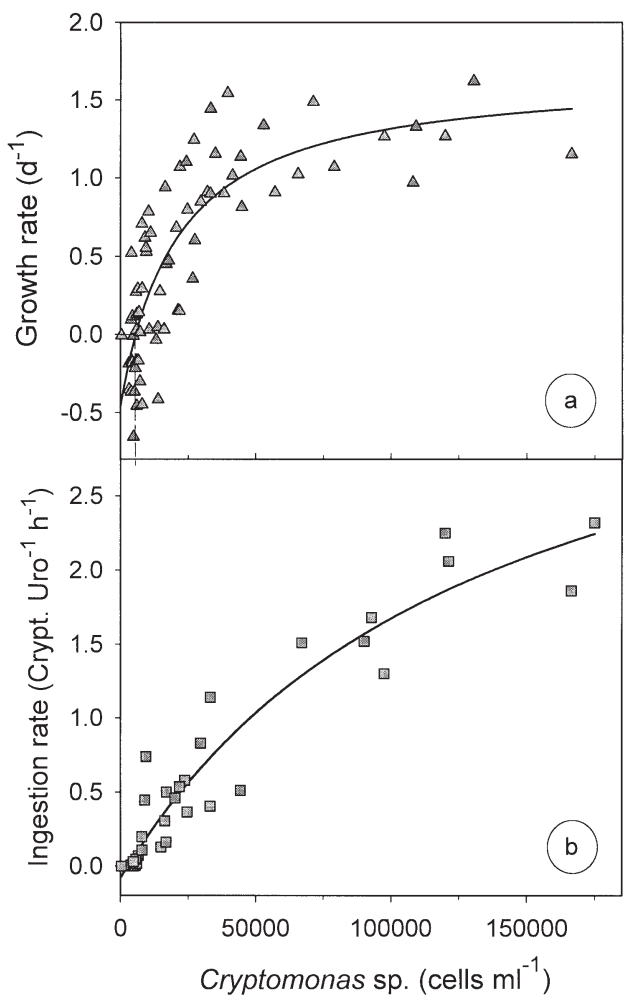

Fig. 4. (a) Growth rates (numerical response) and (b) ingestion rates (functional response) of Urotricha farcta versus food concentration at $15^{\circ} \mathrm{C}$. Solid lines represent the curve fitted according to Eq. (5)
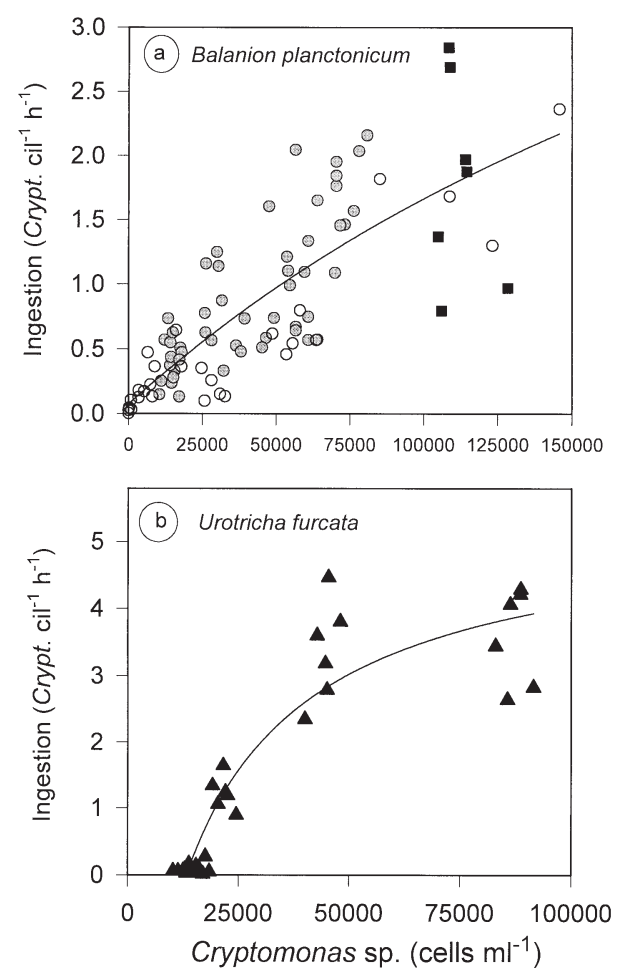
tomonas $\mathrm{ml}^{-1}\left(\sim 390 \mathrm{ng} \mathrm{C} \mathrm{ml} \mathrm{C}^{-1}\right)$, a constant $\mathrm{k}_{\mathrm{t}}$ of $28200 \pm$ 8740 prey cells $\mathrm{ml}^{-1}$ and a maximum ingestion rate of $5.3 \pm 0.7$ Cryptomonas ciliate ${ }^{-1} \mathrm{~h}^{-1}$ for $U$. furcata. All model parameters were significant $(\mathrm{p}<0.0001)$. The feeding threshold is not significantly different from the threshold obtained for its numerical response (Fig. 3b).

Results obtained in the numerical and functional response experiments are summarized in Table 1, which also includes results from similar studies reported in the literature. Note that the ingestion rates reported in Table 1 do not denote maximum ingestion rates predicted by Eq. (5) but correspond to the food concentrations at which growth rates at $15^{\circ} \mathrm{C}$ were maximal. Similarly, GGEs were calculated for the 2 Balanion isolates and the 2 Urotricha spp. at the food concentrations at which maximum growth rates of the respective isolates were measured. Growth efficiencies estimated for fixed cells ranged from 11 to $40 \%$ in the 3 species investigated in this study (Table 1). The GGE reported by Jakobsen \& Hansen (1997) for the marine Balanion sp. B. comatum is higher (32\%) than our and the previous estimates (Müller 1991, Müller \& Schlegel 1999) for the freshwater Balanion sp. The yield of U. farcta was 4fold higher than that of its congener, U. furcata. The GGE values calculated for live cells are higher by approximately one-third due to shrinkage of the ciliates upon Lugol's fixation (Müller \& Geller 1993).

\section{Response to temperature}

The temperature response of Balanion planctonicum isolated from Lake Mondsee was similar to that of the isolate obtained from Lake Constance (Müller \& Geller 1993) but differed in some details (Fig. 6). The isolate from Lake Mondsee grew slower at low $\left(<8^{\circ} \mathrm{C}\right)$ and

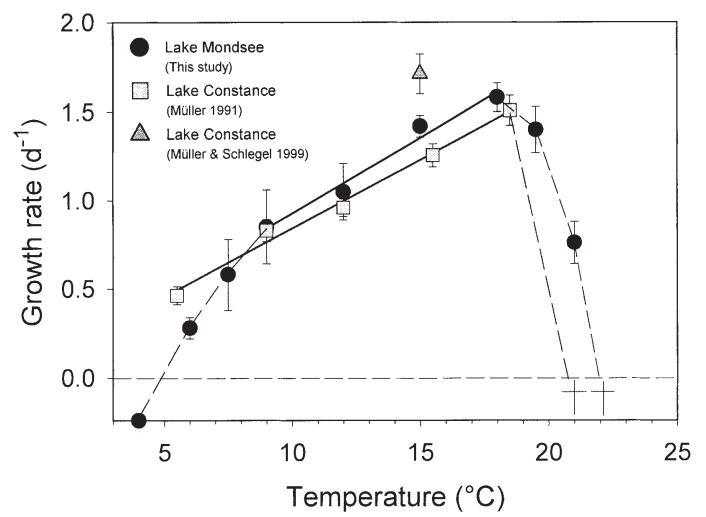

Fig. 6. Temperature response of 3 isolates of Balanion planctonicum. Symbols indicate mean values; error bars $=1 \mathrm{SD}$; solid lines represent least-squares linear regression; dashed lines combine data points not included in the regressions. †: temperatures where ciliate cultures died off faster at high $\left(>18.5^{\circ} \mathrm{C}\right)$ temperatures. From 9 to $18^{\circ} \mathrm{C}$, growth rates of both isolates increased linearly with temperature. The slopes of the respective regression lines were not significantly different (modified $t$-test according to Glantz 1997; $\mathrm{p}=0.063)$. The Lake Constance isolate grew best at $18.5^{\circ} \mathrm{C}$, while $21.5^{\circ} \mathrm{C}$ was lethal (Müller \& Geller 1993). Growth of the Balanion sp. from Lake Mondsee peaked at $18^{\circ} \mathrm{C}$ and then decreased at 19.5 and $21^{\circ} \mathrm{C}$. In the experimental containers exposed to $22^{\circ} \mathrm{C}$, Balanion sp. survived or even grew during the first day of the experiments only, and thereafter rapidly died off.

We conducted similar growth experiments with 3 different small Urotricha spp. and 3 different isolates of the same species, U. furcata, obtained from geographically distant lakes. Overall, the 3 species differed significantly in their temperature response (Fig. 7). $U$. farcta can be characterized as a fast growing, warm water species, reaching growth rates $>1.5 \mathrm{~d}^{-1}$ at temperatures ranging from 20 to $30^{\circ} \mathrm{C}$ (Fig. 7a). Fig. 7a summarizes data from 3 studies (Weisse \& Montagnes 1998, Montagnes \& Weisse 2000, Weisse et al. unpubl.), which investigated in detail specific aspects of the temperature response of $U$. farcta. The most

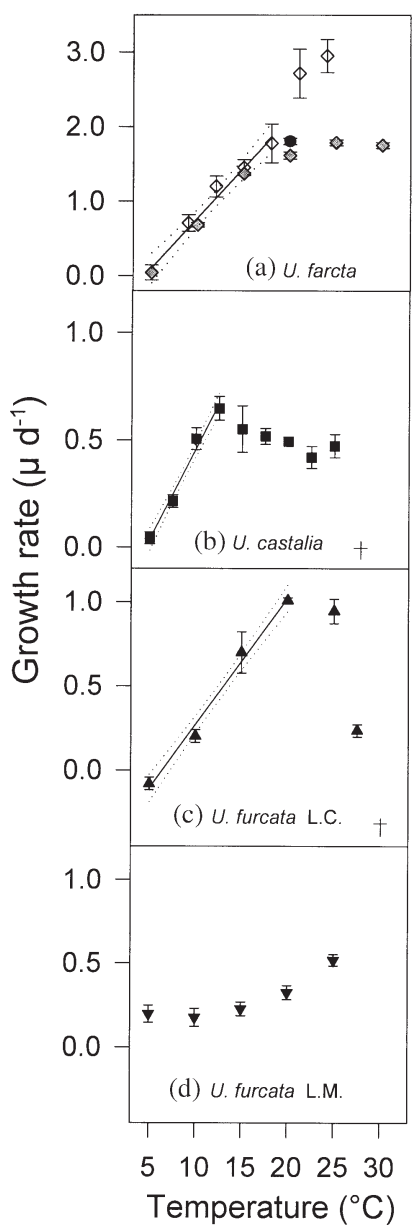

Fig. 7. Temperature response of 3 Urotricha species and 2 isolates of the same species from different lakes. In (a), shaded diamonds denote results from Weisse \& Montagnes (1998); open diamonds denote results from Weisse et al. (unpubl.); the filled circle indicates an experiment conducted by Montagnes \& Weisse (2000) Symbols indicate mean values; error bars $=1 \mathrm{SD}$; solid lines represent least-squares linear regression; broken lines denote $95 \%$ confidence intervals. Note that the scale of the $y$-axis in (a) differs from that in (b) to (d). L.C.: Lake Constance; L.M.: Lake Mondsee 
recent study (Weisse et al. unpubl.) confirmed the earlier results at temperatures ranging from 9 to $18^{\circ} \mathrm{C}$; considerably higher growth rates were, however, measured at 21 and $24^{\circ} \mathrm{C}$. This study differed from the other experiments reported in this paper since prey was kept at higher concentrations $\left(>1 \times 10^{5}\right.$ cells ml $^{-1}$ ) throughout the experiment. We can, therefore, not rule out that the previous studies (Weisse \& Montagnes 1998, Montagnes \& Weisse 2000) had underestimated the maximum growth rates of $U$. farcta at the high temperatures.

Urutricha castalia grew slowly and seemed to be adapted to low temperatures (Fig. 7b). Its maximum growth rate, $0.65 \mathrm{~d}^{-1}$ at $12.5^{\circ} \mathrm{C}$, corresponded to $<1$ doubling $\mathrm{d}^{-1}$. The third species, U. furcata, was intermediate in its growth response. Growth rates peaked at 20 to $25^{\circ} \mathrm{C}$ (Fig. $7 \mathrm{C}$ ); growth declined at $27.5^{\circ} \mathrm{C}$ and was negative at $30^{\circ} \mathrm{C}$. Fig $7 \mathrm{c}, \mathrm{d}$ presents results obtained with non-clonal $U$. furcata isolates from Lake Constance (L.C. in Fig. 7c), south Germany, and Lake Mondsee (L.M. in Fig. 7d), Austria. We also investigated the temperature response of another $U$. furcata isolate obtained from Lakes Schöhsee, north Germany. Since part of this work has already been published (Weisse \& Montagnes 1998), we summarize here only the key findings: the $3 U$. furcata isolates from geographically distant lakes differed markedly in their temperature response. The Mondsee isolate was significantly different from the other 2 isolates at all temperatures. The shape of the temperature response curve of the other $2 U$. furcata isolates was similar but differed in detail. Averaged over the temperature range from 5 and $20^{\circ} \mathrm{C}$, the $U$. furcata from Lake Constance grew slightly but significantly better than that from Lake Schöhsee. Growth rates of these 2 U. furcata isolates were not significantly different at $25^{\circ} \mathrm{C}$, declined at $27.5^{\circ} \mathrm{C}$ and were negative at $30^{\circ} \mathrm{C}$. The Mondsee isolate did not survive at $27.5^{\circ} \mathrm{C}$.

The results of the temperature response experiments are summarized in Table 2, together with the threshold and food concentrations at $k_{t}$ obtained in the numerical response experiments. Table 2 also presents results from similar studies with the same or closely related species reported in the literature.

\section{DISCUSSION}

This is the first study that characterized the ecological niches of sympatric prostome ciliates with respect to temperature and food. We found niche separation at 3 different levels: (1) the temperature and food responses of Balanion planctonicum are clearly different from those of both Urotricha spp. investigated in detail (U. furcata and U. farcta); (2) the relation to temperature was species specific among the 3 Urotricha species, U. furcata, U. farcta and U. castalia; and (3) we found significant intraspecific differences in the growth rates between $2 \mathrm{~B}$. planctonicum and $3 U$. furcata isolates from geographically distant lakes. We will first discuss potential methodological shortcomings of our approach and then characterize the ecological niches of the 4 ciliate species.

\section{Experimental constraints}

As with virtually all laboratory-based extrapolations, experimental artifacts may have resulted from using small containers, only one food species in a particular medium, and protist cultures of variable age and clonal composition. We can rule out that the first point signif-

Table 2. Temperature range of positive population growth, optimum temperature $\left(T_{\text {opt }}\right)$, maximum growth rates $\left(\mu_{\text {max }}\right)$, and threshold and approximate half saturation $\left(\mathrm{k}_{\mathrm{t}}\right)$ food concentrations of Balanion spp. and Urotricha spp. L.C.: Lake Constance; L.M.: Lake Mondsee; L.Sch.: Lake Schöhsee; nd: not determined

\begin{tabular}{|c|c|c|c|c|c|c|c|}
\hline Species & Isolate & $\begin{array}{l}\text { Growth } \\
\text { range }\left({ }^{\circ} \mathrm{C}\right)\end{array}$ & $\begin{array}{l}T_{\mathrm{opt}} \\
\left({ }^{\circ} \mathrm{C}\right)\end{array}$ & $\begin{array}{l}\mu_{\max } \\
\left(d^{-1}\right)\end{array}$ & $\begin{array}{l}\text { Threshold } \\
\left(\mu \mathrm{g} \mathrm{C}^{-1}\right)\end{array}$ & $\left(\mu \mathrm{g} \mathrm{C}^{\mathrm{C}^{-1}}\right)$ & Source \\
\hline \multirow[t]{4}{*}{ Balanion planctonicum } & L.C./1989 & 5 to 18.5 & 18.5 & 1.52 & nd & nd & Müller (1991) \\
\hline & L.C./1993 & nd & nd & $1.87^{\mathrm{a}}$ & 78 & 157 & Müller \& Schlegel (1999) \\
\hline & L.C./1993 & nd & nd & nd & 41 & 136 & This study \\
\hline & L.M./1999 & 6 to 21 & 18.0 & 1.58 & nd & nd & This study \\
\hline \multirow[t]{3}{*}{ Balanion comatum } & Øresund/1995 & $5 \mathrm{nd}$ & nd & nd & 11 & $\sim 15$ & Jakobsen \& Hansen (1997) \\
\hline & L.C./1988 & 5 to $>21.5$ & nd & $1.72^{\mathrm{b}}$ & nd & nd & Müller \& Geller (1993) \\
\hline & L.C./1988 & 6 to 27.5 & 20 to 25 & 1.01 & 383 & 533 & This study \\
\hline \multirow[t]{2}{*}{ Urotricha furcata } & L.Sch./1996 & 8 to 27.5 & 25 & 0.88 & nd & nd & This study \\
\hline & L.M./1996 & 5 to 25 & 25 & 0.52 & nd & nd & This study \\
\hline Urotricha farcta & L.Sch./1996 & 5 to $>30$ & 24 to 27.5 & $1.79 / 2.95^{\mathrm{c}}$ & 163 & 753 & This study \\
\hline Urotricha castalia & L.C./1988 & 0 to 25 & 12.5 & 0.65 & nd & nd & This study \\
\hline
\end{tabular}


icantly affected the results reported, as we have repeatedly measured growth rates of ciliates in containers of variable volume (5 to $500 \mathrm{ml}$ ) and found in short- to medium-term (1 to several days) experiments, no effect related to the experimental volume (Weisse \& Montagnes 1998, Montagnes \& Weisse 2000, Weisse \& Frahm 2001b).

Previous investigations have shown that cryptophytes in the size range from 5 to $15 \mu \mathrm{m}$ are optimum food for small prostome ciliates (Müller 1991, Müller \& Geller 1993, Jakobsen \& Hansen 1997, Weisse \& Müller 1998). This does, however, not preclude some prey-specific differences in ciliate growth and grazing rates. A slightly smaller, unidentified Cryptomonas sp. yielded in some batch cultures higher growth rates in Urotricha furcata than the Cryptomonas strain used in this study (Meyer 1997). We observed that the volume of the prostome ciliates not only changes with food supply (Müller 1991, Jakobsen \& Hansen 1997) but also is variable under standard laboratory conditions, i.e., at a given temperature with the same food species and comparable food levels (Weisse \& Montagnes 1998, Montagnes \& Weisse 2000). Furthermore, the food quality changes with time: exponentially growing cultures of the Cryptomonas sp. strain 26.80 may differ by up to $50 \%$ in their average cell volume measured at $15^{\circ} \mathrm{C}$ (T. Weisse unpubl.).

Food quality may thus affect the numerical and functional response curves of ciliates and is likely to be another important niche parameter in the natural situation. The threshold concentration, i.e., the prey level where the population growth rate is zero, may be lower for Urotricha spp. in the natural environment where an array of various food items is available (Müller et al. 1991, Weisse \& Müller 1998). In spite of this caveat, the comparison of the feeding strategies of the 3 ciliate species should remain valid because the experimental conditions used in this study were internally consistent.

The third potential artifact, variable age and clonal composition of the protist cultures, is difficult to deal with. If sexual processes are prevented, then clonal decay may lead to decreasing ciliate vitality with time (Bell 1988, Montagnes 1996). The Urotricha furcata isolate from Lake Constance was older than the Urotricha spp. and Balanion planctonicum isolates from Lakes Schöhsee and Mondsee. All these isolates were kept as non-clonal, 'mixed' cultures to keep the potential for sexual processes, i.e., conjugation, in our cultures alive. The clonal composition of our cultures is unknown and might have changed with time. A founder effect and differential selection may become important in long-term cultures, in spite of standardized laboratory conditions. All these processes also occur, however, in the natural environment and may further add to the niche dimension of the ciliates. It seems unlikely that clonal decay affected the results reported in this study since our study organisms still had growth rates comparable with those of the juvenile isolates (Weisse \& Montagnes 1998, Montagnes \& Weisse 2000). Growth rates of $U$. furcata (Lake Constance) measured in this study were even slightly higher than the original estimates obtained several years earlier (Müller \& Geller 1993; Table 1).

\section{Ecological niches of prostome ciliates: the response to food concentration and temperature}

\section{Balanion planctonicum}

Our numerical and functional response data support results from similar studies (Jakobsen \& Hansen 1997, Müller \& Schlegel 1999) and suggest that the smallest of the 3 prostome species investigated is the superior competitor at permanently low algal abundances $(<3 \times$ $10^{4}$ Cryptomonas $\mathrm{ml}^{-1}$ ), i.e., at carbon concentrations $<90 \mathrm{ng} \mathrm{C} \mathrm{ml}{ }^{-1}$ or chlorophyll a concentrations $<2.3 \mathrm{ng}$ $\mathrm{ml}^{-1}$, if we convert carbon to chlorophyll by a factor of 40:1 (Montagnes et al. 1994). Balonion planctonicum is able to grow at maximum rates over a wide range of algal concentrations. With respect to the use of the food resources, B. planctonicum may, therefore, have an advantage over the small Urotricha spp. in oligo- to mesotrophic lakes when food is scarce. However, in contrast to both Urotricha spp., B planctonicum cannot survive extended periods of starvation (Fig. 1a). The population size declined strongly over a period of $48 \mathrm{~h}$, which corresponds to $\sim 3$ times the minimum generation time at $15^{\circ} \mathrm{C}$ (Table 1 ) and is similar to the ability of the marine $B$. comatum to withstand starvation (Jakobsen \& Hansen 1997). B. planctonicum is thus dependent upon a constant supply of suitable food.

Balanion planctonicum grew faster than the sympatric Urotricha furcata at low to moderate temperatures $\left(5\right.$ to $\left.18^{\circ} \mathrm{C}\right)$ at saturating food concentrations in laboratory cultures (Müller \& Geller 1993, this study). Negative population growth rates measured in situ during summer when the water temperature in Lake Constance was unusually high $\left(23.2^{\circ} \mathrm{C}\right.$ at $3 \mathrm{~m}$ depth, Weisse \& Müller 1998) support the laboratory findings. B. planctonicum is much more sensitive to high water temperatures than are both small Urotricha sp. This may limit the occurrence of B. planctonicum in temperate areas, in particular during summer in small water bodies that warm up more intensely than large lakes. In accordance with this conclusion, B. planctonicum was not found in the shallow, hypertrophic Danish Lake Søbygård when the temperature exceeded $21^{\circ} \mathrm{C}$ and small Urotricha spp. were highly abundant (Jürgens et al. 1999, see below). 
The vulnerability to competitors and predators may also limit the seasonal occurrence and abundance of the ciliates under study (Müller et al. 1991, Rothhaupt \& Güde 1996, Straile 1998). Relative to the sympatric Urotricha spp., the ecological niche of Balanion planctonicum differs with respect to their susceptibility to rotifers. B. planctonicum is highly susceptible to grazing by the common rotifer species Keratella quadrata (Weisse \& Frahm 2001a) while both $U$. furcata and $U$. farcta seem to have developed a chemically mediated defense mechanism against this rotifer species (Weisse \& Frahm 2001b). B. planctonicum appeared, however, to be unaffected by another rotifer species, $K$. cochlearis, while population growth rates of $U$. furcata were significantly reduced in the presence of K. cochlearis (Weisse \& Frahm 2001a). These and similar experiments (Weisse \& Frahm 2001b) revealed large, species-specific mutual interactions between the ciliates and their coexisting rotifer competitors or predators.

There is some discrepancy in the maximum ingestion rates of Balanion planctonicum reported in the literature (Table 1). We found maximum ingestion rates of $\sim 2$ prey cells ind. ${ }^{-1} \mathrm{~h}^{-1}$ for both isolates investigated, which supports earlier results obtained by flow cytometry (Kenter et al. 1996). The closely related marine species B. comatum also reached maximum per capita ingestion rates of 2 prey cells $\mathrm{h}^{-1}$ when fed a marine small cryptophyte at $15^{\circ} \mathrm{C}$ (Jakobsen \& Hansen 1997). The higher algal uptake rates, up to 4.4 Cryptomonas ind. ${ }^{-1} \mathrm{~h}^{-1}$, reported for the first (1989) B. planctonicum isolate from Lake Constance (Müller 1991), were probably overestimated because ingestion rates were corrected for algal growth in the controls. Without correcting for the growth of the cryptophytes (according to Eqs 2 \& 3), the maximum ingestion rate of B. planctonicum reported by Müller (1991) would be reduced to 2.67 Cryptomonas ind. ${ }^{-1} \mathrm{~h}^{-1}$. The highest maximum ingestion rates of 6 to 8 Cryptomonas ciliate ${ }^{-1} \mathrm{~h}^{-1}$ found in a detailed investigation with the same (1993) $B$. planctonicum isolate from Lake Constance as that used in this study (Müller \& Schlegel 1999) can, however, not be explained by experimental artifacts. Although the reason for the deviating results remains unknown, they point to the significance of clonal differences in growth and grazing rates of common freshwater ciliates (see below).

\section{Urotricha furcata}

In contrast to Balanion planctonicum, Urotricha furcata needs high food concentrations to grow. This finding was obvious both from long-term batch culture experiments (Fig. 1b) and from the numerical (Fig. 3b) and functional response (Fig. 5b). The threshold prey concentration of $\sim 380 \mathrm{ng} \mathrm{C} \mathrm{ml}^{-1}$ is at the high end of threshold concentrations reported by various authors for 13 planktonic ciliate species (summarized by Jakobsen \& Hansen 1997) and comparable with threshold values of freshwater rotifers (reviewed by Walz 1995). Note that such calculations are sensitive to carbon to volume conversion factors used and to the potential effect of cell shrinkage of predator and prey due to fixation. For B. planctonicum and U. furcata the conversion factor between the volume of Lugol's fixed and live cells is 1.36 and 1.42, respectively (Müller \& Geller 1993).

Compared with Balanion planctonicum, the disadvantage resulting from the high food demand may be balanced by the pronounced ability of Urotricha furcata to withstand periods of starvation (Fig. 1b). It is known that some marine and freshwater ciliates can survive without food for relatively long periods (Jackson \& Berger 1984, Fenchel 1990, Montagnes 1996, Jakobsen \& Hansen 1997). The mechanism(s) by which Urotricha sp. survive when food is depleted is unknown. We found no indication for cyst formation. In the oligotrophic to mesotrophic range where food supply is permanently or temporarily scant, $U$. furcata may survive by exploiting patches of high food concentrations. This species seems, however, to be more adapted to eutrophic and hypertrophic environments with permanently high food concentrations. In our stock cultures, U. furcata grew well even when the food concentration was excessively high $\left(>1.5 \times 10^{5}\right.$ prey $\left.\mathrm{ml}^{-1}\right)$. This prey abundance is equivalent to carbon concentrations of $\sim 4.4 \mathrm{mg} \mathrm{C} \mathrm{ml}^{-1}$ or chlorophyll a concentrations of $\sim 110 \mathrm{ng} \mathrm{C} \mathrm{ml}^{-1}$. There is some evidence from the natural environments to support this finding. In the highly eutrophic Danish Lake Søbygård with summer chlorophyll a concentrations between 130 and $730 \mathrm{ng}$ $\mathrm{C} \mathrm{ml}^{-1}$ (Jeppesen et al. 1990), Jürgens et al. (1999) measured concentrations of small Urotricha sp. of up to $300 \mathrm{ml}^{-1}$. High cell numbers of $U$. furcata have also been recorded in eutrophic to hypertrophic ponds, lakes and reservoirs (reviewed by Foissner et al. 1999).

In temperate areas, small, eutrophic water bodies are also often subject to pronounced seasonal temperature changes. It is in accordance with this interpretation that Urotricha furcata is tolerant to a wide range of environmental temperatures. Records of this species are known from Europe, Asia and Australia (summarized by Foissner et al. 1999); these authors propose that $U$. furcata is a cosmopolitan species.

\section{Urotricha farcta}

The third of the prostome species investigated in detail had some features in common with Urotricha 
furcata while it differed markedly in some other respects. Shared characteristics of both Urotricha spp. were the existence of a relatively high critical food concentration necessary to support positive population growth, the tolerance to very high food concentrations (data not shown) and the ability to lead a famine existence for some time. $U$. farcta was the most tolerant of all 4 prostome species investigated with respect to temperature and grew fastest at all temperatures, when food was abundant (Fig. 7). Similar to U. furcata, the threshold concentration derived from the batch cultures and the numerical and functional response experiments were in close agreement. Recent experiments conducted in our laboratory revealed, however, that the threshold for population growth of $U$. farcta is strongly dependent on temperature and may differ with respect to the experimental design (Weisse et al. unpubl.).

In spite of its higher growth rates, the ingestion rate of Urotricha farcta (Fig. 4b) was lower than that of $U$. furcata and comparable with those of both Balanion spp. (Table 1). This explains the high growth efficiency in $U$. farcta, which was also observed in a long-term chemostat experiment (Weisse et al. unpubl). The GGE of $U$. farcta is at the high end of values reported for most ciliates in the literature (reviewed by Straile 1997). Note that the GGE values reported in Table 1 are conservative estimates because we did not convert biovolumes to units of carbon; the carbon to volume ratio may be somewhat higher in ciliates than in most algae (Straile 1997 and references therein).

Our findings are in agreement with the records from different environments for Urotricha farcta. This species is found in ponds, lakes and rivers. It occurs throughout the year and is abundant in eutrophic and hypertrophic water bodies (summarized by Foissner et al. 1999). The temperature span reported for U. farcta from natural environments ranges from 0 to $36^{\circ} \mathrm{C}$ (reviewed by Foissner et al. 1999). We conclude that $U$. farcta is a a euryokous species, best adapted to nutrient-rich, warm water bodies.

\section{Urotricha castalia}

We did not measure the numerical and functional response of this species because, in contrast to the smaller prostomatid ciliates, it is difficult to rear Urotricha castalia at concentrations exceeding 300 cells $\mathrm{ml}^{-1}$. Balanion planctonicum, $U$. furcata and $U$. farcta all reach cell densities of several thousands $\mathrm{ml}^{-1}$ under the laboratory conditions used in this study. At ciliate levels below 200 cells $\mathrm{ml}^{-1}$ calculation of ingestion rates, in particular, is inaccurate, based upon microscopic cell counts. Likewise, changes in cell numbers of $U$. castalia at low food concentrations were too small to measure growth rates with any statistical reliability.

The temperature response measured at saturating food levels revealed that Urotricha castalia is a species adapted to low water temperature. It grew fastest at $12.5^{\circ} \mathrm{C}$ and did not tolerate $27.5^{\circ} \mathrm{C}$ (Fig. 7).

Our experimental findings match the scant reports from natural environments. Muñoz et al. (1987) found Urotricha castalia in an artificial pond in Madrid, Spain from October through May before it was replaced by another Urotricha sp. Foissner \& Pfister (1997) also found $U$. castalia in a highly eutrophic pond at Salzburg, Austria, mainly in late spring. These authors synonymized $U$. rotunda (Fernandez-Leborans \& Novillo 1994), observed in a reservoir $60 \mathrm{~km}$ from Madrid, with U. castalia. U. castalia also occurs in Lake Constance (Weisse \& Müller 1998), from which the isolate used by Foissner \& Pfister (1997) and in the present study originated, but little is known of its ecology. It appears likely that $U$. castalia is more common than indicated by the few literature reports because it is probably often confused with other similar-sized urotrichs with more than 2 caudal cilia (Foissner et al. 1999).

\section{Intraspecific differences}

We have extended the previous investigations on Balanion planctonicum and Urotricha furcata (Müller 1991, Müller \& Geller 1993, Weisse \& Montagnes 1998, Müller \& Schlegel 1999) for an inter- and intraspecific comparison within both genera. Minor differences in the temperature response (at 5 to $25^{\circ} \mathrm{C}$ ) between the non-clonal $U$. furcata isolates from Lakes Schöhsee and Constance had been reported earlier (Weisse \& Montagnes 1998). Major differences were found between these 2 isolates and the one from Lake Mondsee at fluctuating experimental temperatures (Montagnes \& Weisse 2000). We have complemented these previous studies by comparing the temperature response of all 3 isolates over the temperature range from 5 to $30^{\circ} \mathrm{C}$ and confirmed the earlier results: the $U$. furcata strain from Lake Mondsee was strikingly different from its conspecific isolates (Table 2). The intraspecific differences within this species were of similar magnitude to the differences between the 3 Urotricha species studied.

Among Balanion sp., the bioenergetics of the 2 freshwater B. planctonicum strains and the marine B. comatum were generally similar. We measured only minor differences in growth and ingestion rates in response to food and temperature (Table 1), while the B. planctonicum strain studied by Müller \& Schlegel (1999) was 
faster growing and ingested the same or similar prey at rates 3 times higher than the other Balanion isolates.

In conclusion, our results show that the ecological niches of common freshwater ciliates differ species specifically with respect to key environmental parameters such as temperature and food. We also corroborated the earlier conjecture that the ecological niches may not completely overlap in geographically distant populations of the same species (Weisse \& Montagnes 1998, Montagnes \& Weisse 2000). It seems plausible that the niche dimensions of species and populations can be further differentiated if other forms of biological interactions, such as, e.g., mutualism or chemical communication (Larsson \& Dodson 1993), are considered. We therefore caution against the assumption that widely distributed ciliate species behave ecologically identically, i. e., that they occupy identical or very similar niches (Finlay et al. 1996).

Acknowledgements. We thank Helga Müller for providing several ciliate isolates and Peter Stadler for technical assistance in some experiments. Klaus Jürgens provided the Urotricha furcata isolate from Lake Schöhsee. Comments by David Montagnes, H. Müller, Jens Boenigk, Martin Hahn, Nick Crosbie and 3 anonymous reviewers on earlier versions of the manuscript are gratefully acknowledged.

\section{LITERATURE CITED}

Bardele CF (1999) Ultrastructure, morphogenesis, and a discussion on the phylogeny of the prostome ciliate Balanion planctonicum. Eur J Protistol 35:17-33

Bell G (1988) Sex and death in protozoa. Cambridge University Press, Cambridge

Fenchel T (1982) Ecology of heterotrophic microflagellates. II. Bioenergetics and growth. Mar Ecol Prog Ser 8:225-231

Fenchel T (1990) Adaptive significance of polymorphic life cycle in protozoa: responses to starvation and refeeding in two species of marine ciliates. J Exp Mar Biol Ecol 136: 159-177

Fernandez-Leborans G, Novillo A (1994) Three new species of ciliate in the genera Pseudocohnilembus, Pleuronema and Urotricha (Ciliophora). Proc Biol Soc Wash 107: 221-238

Finlay BJ, Corliss JO, Esteban G, Fenchel T (1996) Biodiversity at the microbial level: the number of free-living ciliates in the biosphere. Q Rev Biol 71:221-237

Foissner W, Pfister G (1997) Taxonomic and ecologic revision of urotrichs (Ciliophora, Prostomatida) with three or more caudal cilia, including a user-friendly key. Limnologica 27: 311-347

Foissner W, Oleksiv I, Müller H (1990) Morphologie und Infraciliatur einiger Ciliaten (Protozoa: Ciliophora) aus stagnierenden Gewässern [Morphology and infraciliature of some ciliates (Protozoa: Ciliophora) from stagnant waters]. Arch Protistenkd 138:191-206

Foissner W, Berger H, Kohmann F (1994) Taxonomische und ökologische Revision der Ciliaten des Saprobiensystems. Band III: Hymenostomata, Prostomatida, Nassulida. Informationsber Bayer Landesamt Wasserwirtsch 1/94

Foissner W, Berger H, Schaumburg J (1999) Identification and ecology of limnetic plankton ciliates. Informationsber Bayer Landesamt Wasserwirtsch 3/99

Frost BW (1972) Effects of size and concentration of food particles on the feeding behavior of the marine planktonic copepod Calanus pacificus. Limnol Oceanogr 17:805-815

Glantz SA (1997) Primer of biostatistics. McGraw-Hill, New York

Guillard RRL, Lorenzen CJ (1972) Yellow-green algae with chlorophyllide c. J Phycol 8:10-14

Heinbokel JF (1978) Studies on the functional role of tintinnids in the Southern California Bight. I. Grazing and growth rates in laboratory cultures. Mar Biol 47:177-189

Holling CS (1959) The components of predation as revealed by a study of small-mammal predation of the European pine sawfly. Can Entomol 91:293-320

Jackson KM, Berger J (1984) Survival of ciliated protozoa under starvation conditions and at low bacterial levels. Microb Ecol 10:47-59

Jakobsen HH, Hansen PJ (1997) Prey size selection, grazing and growth response of the small heterotrophic dinoflagellate Gymnodinium sp. and the ciliate Balanion comatum: a comparative study. Mar Ecol Prog Ser 158:75-86

Jeppesen E, Søndergaard M, Sortkjaer O, Mortensen E, Kristensen P (1990) Interactions between phytoplankton, zooplankton and fish in a shallow, hypertrophic lake: a study of phytoplankton collapses in Lake Søbygård, Denmark. Hydrobiologia 191:149-164

Jürgens K, Skibbe O, Jeppesen E (1999) Impact of metazooplankton on the composition and population dynamics of planktonic ciliates in a shallow, hypertrophic lake. Aquat Microb Ecol 17:61-75

Kenter U, Zimmermann U, Müller H (1996) Grazing rates of the freshwater ciliate Balanion planctonicum determined by flow cytometry. J Plankton Res 18:1047-1053

Larsson P, Dodson DI (1993) Chemical communication in planktonic animals. Arch Hydrobiol 129:129-155

Lettner S (2001) Intraspezifische ökophysiologische Unterschiede prostomatider Ciliaten. Diploma thesis, University of Vienna

Macek M, Šimek K, Pernthaler J, Vyhnálek V, Psenner R (1996) Growth rates of dominant ciliates in two freshwater bodies of different trophic degree. J Plankton Res 18: 463-481

Meyer VCL (1997) Wachstums- und Ingestionsraten ökologisch relevanter Süßwasserciliaten. Diploma thesis, Christian-Albrechts-University Kiel

Montagnes DJS (1996) Growth responses of planktonic ciliates in the genera Strobilidium and Strombidium. Mar Ecol Prog Ser 130:241-254

Montagnes DJS, Weisse T (2000) Fluctuating temperatures affect growth and production rates in planktonic ciliates. Aquat Microb Ecol 21:97-102

Montagnes DJS, Berges JA, Harrison PJ, Taylor FJR (1994) Estimating carbon, nitrogen, protein, and chlorophyll a from volume in marine phytoplankton. Limnol Oceanogr 39:1044-1060

Müller H (1989) The relative importance of different ciliate taxa in the pelagic food web of Lake Constance. Microb Ecol 18:261-273

Müller H (1991) Pseudobalanion planctonicum (Ciliophora, Prostomatida): ecological significance of an algivorous nanociliate in a deep meso-eutrophic lake. J Plankton Res 13:247-262

Müller H, Geller W (1993) Maximum growth rates of aquatic ciliated protozoa: the dependence on body size and temperature reconsidered. Arch Hydrobiol 126:315-327

Müller H, Schlegel A (1999) Responses of three freshwater 
planktonic ciliates with different feeding modes to cryptophyte and diatom prey. Aquat Microb Ecol 17:49-60

Müller H, Schöne A, Pinto-Coelho RM, Schweizer A, Weisse $\mathrm{T}$ (1991) Seasonal succession of ciliates in Lake Constance. Microb Ecol 21:119-138

Muñoz A, Téllez C, Fernández-Galiano D (1987) Morphology and infraciliature in Urotricha nais sp. n. and Urotricha castalia sp. n. (Ciliophora, Prorodontida). Acta Protozool 26:197-204

Rothhaupt KO, Güde H (1996) Influence of metazoan zooplankton on the microbial community before and after the onset of the spring clear-water phase in Lake Constance (Bodensee). Arch Hydrobiol Spec Issue Adv Limnol 48: 21-30

Salbrechter M, Arndt H (1994) The annual cycle of protozooplankton in the alpine, mesotrophic Lake Mondsee (Austria). Mar Microb Food Webs 8:217-234

Schönberger M (1994) Planktonic ciliated protozoa of Neusiedler See (Austria/Hungary): a comparison between the turbid open lake and a reedless brown-water pond. Mar Microb Food Webs 8:251-263

Šimek K, Bobková J, Macek M, Nedoma, J, Psenner R (1995) Ciliate grazing on picoplankton in a eutrophic reservoir during the summer phytoplankton maximum: a study at the species and community level. Limnol Oceanogr 40: $1077-1090$

Sommaruga R, Psenner R (1993) Nanociliates of the order Prostomatida: their relevance in the microbial food web of a mesotrophic lake. Aquat Sci 55:179-187

Straile D (1997) Gross growth efficiencies of protozoan and

Editorial responsibility: Karel Šimek,

České Budějovice, Czech Republic metazoan zooplankton and their dependence on food concentration, predator-prey weight ratio, and taxonomic group. Limnol Oceanogr 42:1375-1385

Straile D (1998) Biomass allocation and carbon flow in the pelagic food web of Lake Constance. Arch Hydrobiol Spec Issue Adv Limnol 53:545-563

Walz N (1995) Rotifer populations in plankton communities: energetics and life history strategies. Experientia 51: $437-453$

Weisse T, Frahm A (2001a) Direct and indirect impact of two common rotifer species (Keratella spp.) on two abundant ciliate species (Urotricha furcata, Balanion planctonicum). Freshwater Biol 46 (in press)

Weisse T, Frahm A (2001b) Species-specific interactions between small planktonic ciliates (Urotricha spp.) and rotifers (Keratella spp.). J Plankton Res 23 (in press)

Weisse T, Kirchhoff B (1997) Feeding of the heterotrophic freshwater dinoflagellate Peridiniopsis berolinense on cryptophytes: analysis by flow cytometry and electronic particle counting. Aquat Microb Ecol 12:153-164

Weisse T, Montagnes DJS (1998) Effect of temperature on inter- and intraspecific isolates of Urotricha (Prostomatida, Ciliophora). Aquat Microb Ecol 15:285-291

Weisse T, Müller H (1998) Planktonic protozoa and the microbial food web in Lake Constance. Arch Hydrobiol Spec Issue Adv Limnol 53:223-254

Weisse T, Müller H, Pinto-Coelho RM, Schweizer A, Springmann D, Baldringer G (1990) Response of the microbial loop to the phytoplankton spring bloom in a large prealpine lake. Limnol Oceanogr 35:781-794

Submitted: June 1, 2001; Accepted: August 29, 2001

Proofs received from author(s): October 18, 2001 